\title{
Kondisi Ekonomi, Stigma, dan Tingkat Religiusitas Sebagai Faktor dalam Meningkatkan Upaya Pencegahan Covid-19
}

\author{
Awis Hamid Dani ${ }^{1 *}$,Cucu Herawati ${ }^{1,}$ Herlinawati ${ }^{1}$ Syaeful Bakhri ${ }^{2}$, Lilis Banowati, ${ }^{1}$ Nuniek Tri Wahyuni, ${ }^{3}$ R. \\ Nur Abdurakhman ${ }^{3}$ \\ ${ }^{1}$ Program Studi Kesehatan Masyarakat Sekolah Tinggi Ilmu Kesehatan Cirebon \\ ${ }^{2}$ Fakultas Syariah dan Ekonomi Islam IAIN Syekh Nurjati dari Cirebon \\ ${ }^{1}$ Program Studi S1 Keperawatann Sekolah Tinggi Ilmu Kesehatan Cirebon \\ alwishdani@yahoo.com \\ received 23 Desember 2020; accepted 23 Januari 2021
}

\begin{abstract}
ABSTRAK
Sejak Organisasi Kesehatan Dunia (WHO) menyatakan wabah COVID-19 sebagai pandemi global pada 11 Maret 2020, selain dampaknya menyebabkan masalah kesehatan, psikologis, dan sosial juga mempengaruhi aktivitas ekonomi di seluruh dunia terganggu. yang menyebabkan implikasi ekonomi jangka panjang dan cukup besar, hal ini mempengaruhi Pemerintah dan masyarakat dalam upaya pencegahan dan penanggulangan Covid-19, karena beberapa negara memberlakukan lockdown, karantina, tetap tinggal di rumah, penutupan bisnis, dan larangan perjalanan. Tujuan penelitian ini untuk mengetahui hubungan antara stigma, kecemasan, tingkat religiusitas dan kondisi ekonomi dengan upaya pencegahan Covid-19 pada masyarakat.Jenis penelitian menggunakan deskriptif analitik dengan desain cross sectional, pengumpulan data dengan cara survei menggunakan instrumen kuesioner melalui googleformonline. Populasi dalam penelitian ini sebanyak 86 responden di wilayah Cirebon Jawa Barat Indonesia. Analisis statistik menggunakan analisis bivariat dengan chi-square dan multivariat regresi logistik.Hasil penelitian diperoleh ada hubungan antarakondisi ekonomidenganupayapreventif Covid-19 dengan nilai $\mathrm{p}$ value $0,001 \quad(<0,05)$. Ada hubungan antara stigma denganupayapreventif Covid-19dengan nilai $\mathrm{p}$ value0,001.Adahubungan antaratingkatreligiusitasdenganupayapreventif Covid-19 dengan nilai $\mathrm{p}$ value0,022. Sedangkan tidak ada hubungan antara kecemasan dengan upaya preventif Covid-19 dengan nilai $\mathrm{p}$ value 0,933 . Kondisi ekonomi merupakan variabel yang paling berpengaruhterhadapupayapreventif covid19dengan odds ratio (OR) 5,7 dan mempunyai nilai koefisien regresi sebesar 0,63 artinya seseorang yang memiliki kondisi ekonominya baik memiliki probabilitas untuk melakukan upaya preventif yang tinggi sebesar $63 \%$.
\end{abstract}

Kata Kunci: Ekonomi, kecemasan, religiusitas, stigma,pencegahan

\begin{abstract}
Since the World Health Organization (WHO) declared the COVID-19 outbreak a global pandemic on March 11, 2020, in addition to its impact causing health, psychological and social problems it also affects economic activity around the world which cannot cause long-term and considerable economic implications. This affects the Government and society in efforts to prevent and control Covid-19, as several countries impose lockdowns, quarantine, stay at home, business closures, and travel bans. The purpose of this study was to see the relationship between stigma, reduced levels of religiosity, and economic conditions with efforts to prevent Covid-19 in society.This type of research uses descriptive-analytic with a cross-sectional design and asks for data using a survey using a questionnaire instrument via an online google form. The population in this study was 86 respondents in Cirebon, West Java, Indonesia. Statistical analysis used bivariate analysis with chi-square and multivariate logistic regression.The results showed that there was a relationship between economic conditions and efforts to prevent Covid-19 with a value of $\mathrm{p}$ value $0.001(<0.05)$. There is a relationship between stigma and efforts to prevent Covid-19 with $\mathrm{p}$ value of 0.001 . There is a relationship between the level of religiosity and efforts to prevent Covid-19 with $p$ value of 0.022 . Meanwhile, there is no relationship between prevention and efforts to prevent Covid-19 withp value of 0.933 . Economic conditions are the most influential variables on the prevention of Covid-19 with an odds ratio (OR) of 5.7 and have a regression coefficient value of 0.63 , meaning that someone who has a good economic condition has a high probability of taking preventive measures at $63 \%$.
\end{abstract}

Keywords: Anxiety, economy, religiosity,stigma, prevention 


\section{Pendahuluan}

Strategi pencegahan dan pengendalian COVID19 dirumuskan dari sudut pandang individualistik yang ditopang oleh kebebasan dan hak individu, dengan pandangan jangka panjang untuk mempertahankan fungsi yang baik yaitu sistem kesehatan, sosial dan ekonomi. ${ }^{1}$ Tutupnya layanan masyarakat dan industri berdampak negatif bagi perekonomian, kerugian finansial, pengangguran, sehingga mempengaruhi emosi negatif masyarakat. ${ }^{2}$ Dampak ekonomi juga meningkat seperti penghentian produksi, terganggunya operasi bisnis, dan pembatasan pergerakan orang yang mengakibatkan kerugian bagi bisnis dan hilangnya mata pencaharian dan pendapatan bagi pekerja. ${ }^{3}$ Dengan adanya krisis ekonomi akibat pandemi Covid-19 ini dapat mempengaruhi masyarakat dalam upaya pencegahan dan penanggulangan Covid-19.

Penularan Covid-19 memunculkan berbagai sikap, kepercayaan, prasangka, stereotip, dan stigma petugas kesehatan kepada pasien, ketakutan utama adalah terinfeksi. Stigma merupakan masalah yang sangat mendesak bagi sistem kesehatan nasional dan sebagai krisis kesehatan. ${ }^{4}$

Percepatan penyebaran COVID-19 dan dampaknya telah membuat orang-orang ketakutan, panik, khawatir, dan cemas merupakan stigma sebagai penyakit sosiopsikologis. ${ }^{5}$ Hal ini terjadi karena banyaknya isu yang beredar yang tidak benar dan tidak adanya pemfilteran informasi yang diterima masyarakat sehingga membuat mereka semakin panik. $^{6}$ Stigma sosial berupa diskriminasi, pelecehan, dan kebencian marak di masyarakat karena sulit untuk menentukan siapa yang membawa virus dan siapa yang bukan. ${ }^{5}$

Pandemi Covid-19 tidak hanya membawa risiko kematian akibat infeksi virus tetapi juga masalah kesehatan mental masyarakat, seperti gejala kecemasan dan depresi. ${ }^{7}$

Ketakutan karena COVID-19 berdampak besar pada kesehatan mental masyarakat dan mempengaruhi perilaku protektif setiap orang. ${ }^{8}$ Situasi pandemi menyebabkan masalah kesehatan mental seperti stres, kecemasan, gejala depresi, insomnia, penolakan, kemarahan dan ketakutan. Masalah-masalah kesehatan mental ini dapat memiliki efek jangka panjang pada kesejahteraan mereka secara keseluruhan. ${ }^{9}$ Anjuran untuk tetap tinggal dirumah menyebabkan perubahan dalam kehidupan sehari-hari hal ini menyebabkan tingkat kecemasan dan kekhawatiran yang dirasakan meningkat, gejala-gejala ini cenderung mengurangi dampak COVID-19. ${ }^{10}$

Tindakan pencegahan dan pengendalian infeksi terkait Pandemi COVID-19, pemicu stres di masyarakat. Religiusitas adalah rasa memiliki atas keyakinan agama, yang memunculkan komitmen untuk praktik terkait misalnya, berdoa, berpuasa, dan membaca kitab suci. $^{11,12}$ Situasi pandemi covid-19 ini meningkatkan kekhawatiran tentang pentingnya peran religiusitas sebagai mekanisme koping dalam menghadapi pandemi Covid-19. ${ }^{13,14}$ Pada masa pandemi Covid-19, agama memiliki peran yang besar bagi individu sebagai strategi coping. Sesuai dengan pendapat Argyle, yang menyebutkan bahwa religiusitas membantu individu mempertahankan kesehatan psikologis pada saat-saat sulit. Religiusitas juga sangat membantu individu ketika mereka harus mengatasi peristiwa yang tidak menyenangkan. ${ }^{15}$

Seseorang yang memiliki sikap religius yang tinggi cenderung akan melakukan perilaku prososial. ${ }^{16}$ Penelitian epidemi H1N1, terlihat bahwa proporsi yang signifikan dari masyarakat umum tidak menyadari keseriusan dan langkah-langkah pencegahan epidemi. ${ }^{17}$ Tujuan dari penelitian ini untuk mengetahui hubungan antara stigma, kecemasan, tingkat religiusitas dan kondisi ekonomi dengan upaya pencegahan Covid-19 pada masyarakat. 


\section{Metode}

Jenis penelitian ini menggunakan deskriptif analitik dengan desain cross sectional, pengumpulan data dengan cara survei menggunakan instrumen kuesioner melalui googleformonline. Sampel dalam penelitian ini sebanyak 86 responden di Wilayah Cirebon Jawa Barat Indonesia. Kriteria inklusi dalam penelitian ini yaitu responden yang bersedia dijadikan sampel penelitian dan sehat jasmani, sedangkan kriteria ekslusi dalam penelitian ini yaitu penderita Covid-19. Variabel yang diteliti pada penelitian ini yaitu stigma, tingkat kecemasan, kondisi ekonomi, dan tingkat religiusitas.

Definisi operasional stigma yaitu label negatif yang melekat terhadap pasien Covid-19 meliputi stereotipe, penerimaan diri, pengungkapan masalah dan hubungan sosial. Tingkat kecemasan yaitu ketakutan atau kekhawatiran yang mendalam atau ketegangan mental sebagai reaksi umum dari ketidakmampuan mengatasi suatu masalah, yang menimbulkan perubahan fisiologis dan psikologis masyarakat terhadap pandemi Covid-19. Kondisi ekonomi yaitu kemampuan masyarakat secara finansial dalam upaya pencegahan dan penanggulangan Covid-19. Tingkat religiusitas adalah persepsi seseorang dalam meyakini agamanya, yang diwujudkan dalam mematuhi serta menjalankan kewajibankewajibannya pada saat menghadapi pandemi Covid-19.

Kuesioner yang digunakan untuk tingkat kecemasan menggunakan kuesioner HARS (hamilton anxiety rating scale) sedangkan untuk variabel stigma, kondisi ekonomi, dan tingkat religiusitas menggunakan kuesioner yang dikembangkan oleh peneliti berdasarkan teori dan penelitian sebelumnya dengan uji validitas dan reliabilitas terlebih dahulu. Analisis statistik menggunakan analisis bivariat dengan Chi-Square dan multivariat regresi logistik.

\section{Hasil}

Tabel 1.Karakteristik Responden

\begin{tabular}{|c|c|c|}
\hline \multirow{2}{*}{$\begin{array}{l}\text { Karakteristik } \\
\text { Usia (tahun) }\end{array}$} & n \% & Mean \pm SD \\
\hline & & $35.05 \pm 7.620$ \\
\hline Jenis kelamin & & \\
\hline - Laki-laki & $32(37,2.9)$ & \\
\hline - Perempuan & $54(62.8)$ & \\
\hline Pekerjaan & & \\
\hline - Paramedis & & \\
\hline (Perawat, & $55(64 \%)$ & \\
\hline $\begin{array}{l}\text { Bidan, } \\
\text { SKM) }\end{array}$ & $31(36 \%)$ & \\
\hline $\begin{array}{ll}\text { - Bukan } \\
\text { paramedis } \\
\text { (Masyarakat } \\
\text { umum) }\end{array}$ & & \\
\hline Jumlah & $86(100)$ & \\
\hline
\end{tabular}

Berdasarkan tabel 1. diperoleh karakteristik responden rata-rata mempunyai usia 35,05 tahun, sebagaian besar perempuan $54(62,8 \%)$, dan pekerjaan responden sebagian besar paramedis (Perawat, Bidan, dan Sarjana Kesehatan Masyarakat) 55 (64\%) dan bukan paramedis sebesar 31 (36\%).

Tabel 2.Distribusi Frekuensi Stigma, Kecemasan, Tingkat Religiusitas, dan Kondisi Ekonomi

\begin{tabular}{lcc}
\hline Variabel & Frekuensi & $\begin{array}{l}\text { Persentase } \\
(\%)\end{array}$ \\
\hline Stigma & 34 & 39,5 \\
$\begin{array}{l}\text { 1. Rendah } \\
\text { 2. Tinggi }\end{array}$ & 52 & 60,5 \\
Tingkat Kecemasan & & \\
1. Tidak ada & 59 & 68,6 \\
Kecemasan & 15 & 17,4 \\
2. Kecemasan Ringan & 10 & 11,6 \\
3. Kecemasan Sedang & 2 & 2,3 \\
$\begin{array}{l}\text { 4. Kecemasan Berat } \\
\text { Tingkat Religiusitas }\end{array}$ & & \\
Rendah & 20 & 23,3 \\
Tinggi & 66 & 76,7 \\
Kondisi Ekonomi & & \\
Tidakbaik & 34 & 39,5 \\
Baik & 52 & 60,5 \\
Upaya Preventif & & \\
Rendah & 43 & 50,0 \\
Tinggi & 43 & 50,0 \\
\hline Jumlah & $\mathbf{8 6}$ & $\mathbf{1 0 0}$ \\
\hline
\end{tabular}


Tabel 3. Hubungan antara Stigma, Tingkat Kecemasan, Kondisi Ekonomi, dan Religiusitasdengan Upaya Preventif Covid-19

\begin{tabular}{|c|c|c|c|c|c|c|c|}
\hline \multirow{3}{*}{ Variabel } & \multicolumn{4}{|c|}{ Upaya Pencegahan } & \multirow{2}{*}{\multicolumn{2}{|c|}{ Jumlah }} & \multirow{3}{*}{ P-value } \\
\hline & \multicolumn{2}{|c|}{ Rendah } & \multicolumn{2}{|c|}{ Tinggi } & & & \\
\hline & $\mathbf{n}$ & $\%$ & $\mathrm{n}$ & $\%$ & $\mathrm{n}$ & $\%$ & \\
\hline Stigma & & & & & & & 0.001 \\
\hline \multirow{2}{*}{$\begin{array}{l}\text { Rendah } \\
\text { Tinggi }\end{array}$} & 25 & 73,5 & 9 & 26,5 & 34 & 100 & \\
\hline & 18 & 34,6 & 34 & 65,4 & 52 & 100 & \\
\hline $\begin{array}{l}\text { Tingkat } \\
\text { kecemasan }\end{array}$ & & & & & & & 0.933 \\
\hline Tidak cemas & 27 & 45,8 & 32 & 54,2 & 59 & 100 & \\
\hline Ringat & 7 & 46,7 & 8 & 53,3 & 15 & 100 & \\
\hline Sedang & 4 & 40,0 & 6 & 60,0 & 10 & 100 & \\
\hline Berat & 2 & 100 & 0 & 0 & 2 & 100 & \\
\hline $\begin{array}{l}\text { Tingkat } \\
\text { religiusitas }\end{array}$ & & & & & & & 0.022 \\
\hline \multirow{2}{*}{$\begin{array}{l}\text { Rendah } \\
\text { Tinggi }\end{array}$} & 15 & 75,0 & 5 & 25,0 & 20 & 100 & \\
\hline & 28 & 42,4 & 38 & 57,6 & 66 & 100 & \\
\hline Kondisi ekonomi & & & & & & & 0.001 \\
\hline Tidak baik & 25 & 73,5 & 9 & 26,5 & 34 & 100 & \\
\hline Baik & 18 & 34,6 & 34 & 65,4 & 52 & 100 & \\
\hline
\end{tabular}

Berdasarkan tabel 3. menunjukkan bahwa responden yangmemiliki stigma rendah, sebagian besar $(73,5 \%)$ melakukan upaya preventif yang rendah, sedangkan responden yang memiliki stigma yang tinggilebihsebagianbesar $\quad(65,4 \%)$ melakukanupayapreventif yang tinggi. Nilai $\mathrm{p}$ value $=0,001 \quad(<0,05)$ yang berarti ada hubungan antara stigma dengan upaya preventif Covid-19. Responden yang tidak mengalami kecemasan dan melakukan upaya preventif tinggi $(54,2 \%)$ dan yang mengalami kecemasan sedang sebagian besar $(60,0 \%)$ melakukan upaya preventif tinggi. Nilai $\mathrm{p}$ value $=0,933$ $(>0,05)$ yang berarti tidak ada hubungan antara kecemasan dengan upaya preventif Covid-19.

Responden yang tingkat religiusitasnya rendah, sebagian besar $(75,0 \%)$ melakukan upaya preventif yang rendah, sedangkan responden yang tingkat religiusitasnya tinggi sebagian besar(57,6\%) melakukan upayap reventif yang tinggi. Nilai $p$ value $=0,022(<0,05)$ yang berarti ada hubungan antara tingkat religiusitas dengan upaya preventif Covid-19. Responden yang kondisi ekonominya tidak baik,s ebagianbesar melakukanupayapreventif yang rendah, sedangkan responden yang kondisi ekonominya baik sebagian besar $(65,4 \%)$ melakukan upaya preventif yang baik. Nilai $\mathrm{p}$ value $=0,001 \quad(<0,05)$ yang berarti ada hubungan antara kondisi ekonomi dengan upaya preventif Covid-19.

Tabel 4. Pemodelan Regresi Logistik Pemodelan Pertama

\begin{tabular}{|c|c|c|c|c|}
\hline Variabel & B & Pvalue & OR & $95 \% \mathrm{CI}$ \\
\hline 1. Stigma & 1,701 & 0,002 & 5,480 & $1,870-$ \\
\hline 2. Tingkat & 0,995 & 0,129 & 2,704 & 16,058 \\
\hline $\begin{array}{l}\text { Religiusit } \\
\text { as }\end{array}$ & 1,751 & 0,001 & 5,758 & $\begin{array}{l}0,749- \\
9,764\end{array}$ \\
\hline $\begin{array}{l}\text { 3. Kondisi } \\
\text { Ekonomi }\end{array}$ & & & & $\begin{array}{l}1,972- \\
16,820\end{array}$ \\
\hline
\end{tabular}

Dari pemodelan pertama terlihat ada 1 variabel yang $\mathrm{p}$ valuenya $>0,05$ yaitu tingkat religiusitas. Selanjutnya melakukan eliminasi variable yang mempunyai Pvalue $>0,05$ dan dikeluarkan dari model yaitu variable tingkat religiusitas

Tabel 5. Hasil Pemodelan Terakhir Regresi Logistik

\begin{tabular}{llllll}
\hline Variabel & B & Pvalue & OR & $\mathbf{9 5 \%}$ CI \\
\hline 1. Stigma & 1,701 & 0,002 & 5,480 & $1,870-$ & \\
2. Tingkat & 0,995 & 0,129 & 2,704 & 16,058 & \\
Religiusitas & 1,751 & 0,001 & 5,758 & 0,749 & - \\
3. Kondisi & & & & 9,764 & \\
Ekonomi & & & & 1,972 & - \\
& & & & 16,820 & - \\
\hline
\end{tabular}

Hasilanalisis multivariat, variable yang paling dominan berpengaruh terhadap upaya preventif covid-19 adalah kondisi ekonomi dengan Odds Ratio (OR) 5,7 (95\% CI: 1,33810,05), artinyaindividu yang kondisi ekonominya kurang baik mempunyai resiko sebesar 6 kali untuk melakukan upaya preventif yang rendah dibandingkan dengan individu yang kondisi ekonominya baik. Nilai koefisien regresi yang terdapat pada analisis multivariat sebesar 0,63 artinya seseorang yang memiliki stigma tinggi dan kondisi ekonominya baik memiliki probabilitas untuk melakukan upaya preventif yang tinggi sebesar $63 \%$. 


\section{Pembahasan}

\subsection{Kondisi ekonomi dengan upaya pencegahan Covid-19}

Hasil penelitian inidiperoleh nilai $\mathrm{p}$ value 0,001 yang berartiada hubungan antara kondisi ekonomi dengan upaya preventif Covid-19, sejalan dengan beberapa penelitian sebelumnya yang menyatakan pandemi COVID-19 selain menyebabkan kematian dan efek kesehatan masyarakat, mempengaruhi implikasi ekonomi yang signifikan dan bertahan lama, termasuk hilangnya produktivitas, hilangnya mata pencaharian, gangguan rantai pasokan, dan potensi tekanan keuangan pada bisnis dan rumah tangga. ${ }^{3}$ Pandemi COVID-19 bukan hanya menyebabkan krisis kesehatan masyarakat, juga sangat mempengaruhi ekonomi global dan pasar keuangan. Penurunan pendapatan yang signifikan, peningkatan pengangguran, industri, transportasi, jasa, dan manufaktur adalah beberapa konsekuensi dari tindakan mitigasi penyakit yang telah diterapkan di banyak negara. ${ }^{18}$

Pada penelitian ini kondisi ekonomi merupakan variabel yang paling berpengaruh terhadap upaya preventif covid-19dengan OddsRatio (OR) 5,7 dan mempunyai nilai koefisien regresi sebesar 0,63 artinya seseorang yang memiliki kondisi ekonominya baik memiliki probabilitas untuk melakukan upaya preventif yang tinggi sebesar $63 \%$. Responden pada penelitian ini yaitu paramedis yang terdiri dari Perawat, Bidan, Sarjana Kesehatan Masyarakat dan masyarakat umum, yang mempunyai tingkat sosial ekonomi yang berbeda ada yang kurang, cukup dan baik sehingga mampu melakukan upaya pencegahan Covid-19 yang meliputi memakai masker, mencuci tangan dengan sabun, menjaga jarak minimal 1 meter apabila berinterkasi dengan orang lain, istirahat yang cukup dan makan makanan yang bergizi. Jadi masyarakat melakukan upaya pencegahan Covid-19 sangat tergantung pada keadaan sosial ekonominya masing-masing.Tingkat sosial ekonomi meliputi pendidikan, pendapatan, dan pekerjaan yang merupakan penyebab secara tidak langsung dari masalah kesehatan. Pekerjaan seseorang dapat mengukur status sosial ekonomi serta masalah kesehatan dan kondisi tempat seseorang bekerja. ${ }^{19}$ Pandemi Covid-19 berdampak negatif pada ekonomi ASEAN dan seluruh dunia, sektor-sektor utama telah terpengaruh, terutama sektor pariwisata, ritel, jasa, bisnis, pekerjaan dan mata pencaharian. Perhatian khusus diberikan kepada kelompok rentan yang paling terpengaruh misalnya pekerja informal atau pekerja harian, pekerja industri, orang miskin, dan lansia. ${ }^{3}$ Jenis pekerjaan responden dapat menggambarkan kondisi ekonomi masyarakat sehingga berpengaruh terhadap kebiasaan responden untuk dapat melakukan pencegahan dan penanggulangan Covid-19.

Lockdown memberikan kontribusi pada ekonomi global. Seiring dengan dampak ekonomi, morbiditas dan mortalitas yang semakin meningkat karena COVID-19 mengalami kemunduran terbesar diberbagai negara. ${ }^{17}$ Pandemi covid menyebabkan standar hidup yang lebih rendah karena tekanan ekonomi sehingga dapat menyebabkan nutrisi lebih buruk, yang berpotensi mengurangi kekebalan karena dengan tingkat stres yang lebih tinggi. ${ }^{20}$ Dengan ditutupnya layanan masyarakat dan runtuhnya industri yang berdampak negatif bagi perekonomian, banyak orang berakhir dengan kerugian finansial dan risiko pengangguran, yang semakin mengintensifkan emosi negatif yang dialami oleh individu. $^{2}$

COVID-19 dikaitkan dengan beban yang signifikan dari kesulitan psikologis dan sosialekonomi, karena kedua dampak langsung dari infeksi dan langkah-langkah ketat yang diperlukan untuk mengurangi penyebarannya. ${ }^{21}$ Pekerjaan juga menentukan besarnya penghasilan yang diterima oleh seseorang masyarakat dengan penghasilan yang rendah sering mengalami kesulitan mendapatkan pelayanan kesehatan yang baik. ${ }^{19}$ Responden pada penelitian ini sebanyak $64 \%$ paramedis (Perawat, Bidan dan Sarjana Kesehatan Masyarakat), maka risiko tertularnya Covid-19 merupakan kerentanan terbesar, karena 
sebagian besar petugas layanan kesehatan tidak dapat bekerja dari jarak jauh.

\subsection{Stigmadengan upaya pencegahan Covid- 19}

Hasil penelitian menunjukkan responden yang memiliki stigma yang tinggi sebagian besar $(65,4 \%)$ melakukan upaya preventif yang tinggi. Nilai Pvalue $=0,001 \quad(<0,05)$ yang berarti ada hubungan antara stigma dengan upaya preventif Covid-19. Hasil penelitian ini sejalan dengan beberapa hasil penelitian sebelumnya yang menyatakan apabila perceived stigma pada penderita sangat tinggi dapat memberikan efek yang kurang baik tehadap proses kepatuhan minum obat. ${ }^{22}$ Upaya pencegahan penyebaran Covid-19 terganggu oleh munculnya stigma sosial di masyarakat, di masa lalu, stigma dikaitkan dengan berbagai penyakit menular dan mengakibatkan diskriminasi terhadap kelompok pasien tersebut, yang menimbulkan konsekuensi negatif baik pada individu maupun masyarakat. ${ }^{23}$

Stigma diri mengandung tiga komponen kognisi yaitu sterotip, prasangka, dan diskriminasi dalam stigma publik yang dapat mempengaruhi perilaku. ${ }^{24}$ Ketakutan yang tidak proporsional, muncul karena kurangnya informasi, banyaknya informasi yang salah dan tidak adanya kepercayaan pada sistem kesehatan memicu munculnya stigma sosial. ${ }^{5}$ Hilangnya kepercayaan pada layanan kesehatan serta stigma mengakibatkan gangguan interaksi di masyarakat. ${ }^{25}$ Kesadaran yang memadai dapat meminimalkan stigmadan memfasilitasi penerimaan di masyarakat. ${ }^{17}$

Responden pada penelitian ini sebagian besar paramedis, diperoleh responden yang memiliki stigma tinggi(60,5\%).Stigma memiliki dampak tinggi pada kinerja petugas kesehatan, dapat memengaruhi kepatuhan pekerja dan menjadi strategi komunikasi manajemen terkait dengan risiko pandemi bagi petugas kesehatan. ${ }^{26}$ Stigmatisasi petugas kesehatan dikaitkan dengan kesehatan psikologis dan fisik. Petugas kesehatan yang diperkirakan akan mengalami tingkat stigmatisasi yang lebih tinggi, peningkatan tekanan psikologis, dan dapat meningkatkan gejala somatik. ${ }^{4}$

Stigma sosial negatif yang muncul di masyarakat sebagian besar disebabkan oleh penolakan karena takut tertular COVID-19. Banyak orang menolak untuk memulihkan pasien yang kembali ke wilayah mereka, menolak keluarga pasien, menolak petugas kesehatan dan semua individu yang mencurigakan dan pengawasan. Pendidikan kesehatan, terutama bagi masyarakat awam, membutuhkan teknik yang tepat agar mudah diterima. ${ }^{6}$ Untuk mengubah sikap, sangat penting bahwa seorang pasien secara konsisten terpapar informasi baru yang dapat terintegrasi ke dalam pandangannya, psikoedukasi secara signifikan mengurangi persepsi stigma dan memberikan penanganan yang lebih besar setelah pengobatan di antara pasien dengan penyakit mental kronis. ${ }^{27}$

\subsection{Tingkat Religiusitas dengan upaya pencegahan Covid-19}

Hasil penelitian menunjukkan diperoleh nilai Pvalue $=0,022 \quad(<0,05)$ yang berarti ada hubungan antara tingkat religiusitas dengan upaya preventif Covid-19. Hasil penelitian ini sejalan dengan beberapa hasil penelitian sebelumnya yang menyatakan beberapa penelitian menyimpulkan bahwa tingginya religiusitas berpengaruh terhadap rendahnya stres,khususnya ditempat kerja. ${ }^{28}$ Religiusitas membantu individu mengatasi peristiwa yang tidak menyenangkan. Agama mampu menyediakan sumber untuk menjelaskan dan menyelesaikan situasi problematik, meningkatkan perasaan berdaya dan mampu efikasi pada diri seseorang, serta menjadi landasan perasaan bermakna, memiliki arah, serta secara potensial menanamkan perilaku yang baik. ${ }^{15}$ Semakin tinggi religiusitas maka semakin tinggi pula perilaku prososialnya, sebaliknya semakin rendah religiusitas maka semakin rendah pula perilaku prososialnya. ${ }^{16}$ Sikap religius yang tinggi terhadap penghayatan ajaran agamanya, maka seorang individu akan memperoleh cara yang terbaik 
dalam menentukan atau menghadapi segala permasalahan hidup yang dialaminya. ${ }^{29}$

Makna religiusitas didefinisikan sebagai sejauh mana seseorang percaya, memandang hal-hal yang terjadi sehari-hari berdasarkan sudut pandang agama dan menerapkan keyakinan agamanya. ${ }^{15}$ Religiusitas berpengaruh terhadap perilaku moral masyarakat ${ }^{30}$ Wabah COVID-19 sebagai krisis spiritual di banyak negara, yang haknya untuk menghadiri layanan keagamaan dan pertemuan telah sangat dibatasi atau dihapuskan karena perlunya tindakan pengendalian infeksi, termasuk lockdown dan karantina. Agama juga memainkan peran penting dalam menumbuhkan dan mempertahankan harapan dalam menghadapi penyakit dan kematian. ${ }^{21}$ Agama dapat menumbuhkan dan mempertahankan harapan dalam menghadapi penyakit dan kematian. ${ }^{31}$

Salah satu cara menjaga kesehtanjiwa adalah meningkatkan faktor religiositas atau aspek keyakinan terhadap agama.Beberapa penelitian menyimpulkan bahwa tingginya religiusitas berpengaruh terhadap rendahnya stres, khususnya ditempatkerja. ${ }^{28}$ Kehidupan komunitas keagamaan dan kehadiran ritual dapat membantu memperkuat individu untuk tidak terlibat dalam perilaku berisiko. ${ }^{32}$ Dalam penelitian ini yaitu perilaku berisiko dimana masyarakat tidak patuh terhadap upaya pencegahan covid 19 yang meliputi memakai masker, mencuci tangan dengan sabun, menjaga jarak minimal 1 meter apabila berinterkasi dengan orang lain, istirahat yang cukup dan makan makanan yang bergizi. Dimana upaya pencegahan Covid-19 tergantung pada pemahaman dan perilaku masyarakat dalam kehidupan beragama seharai-hari.

\subsection{Tingkat kecemasandengan upaya pencegahan Covid-19}

Hasil penelitian menunjukkan diperoleh nilai $\mathrm{p}$ value $=0,933(>0,05)$ yang berarti tidak ada hubungan antara kecemasan dengan upaya preventif Covid-19. Hasil penelitian ini sejalan dengan beberapa hasil penelitian sebelumnya yang menyatakan tidak ada hubungan yang signifikan dengan kecemasan dan kewaspadaan penyebaran Covid19 di Nusa Tenggara Barat pada situasi pandemi. ${ }^{33}$ Tidak ada hubungan yang signifikan antara depresi dan kecemasan dengan kewaspadaan untuk pencegahan selama wabah COVID-19 di Wilayah Kurdistan Irak. ${ }^{34}$ Responden kurang cemas tentang status kesehatan mereka dan cenderung tidak melakukan tindakan pencegahan seperti mencuci tangan dan menghindari ruang yang ramai. ${ }^{8}$

Penelitian sebelumnya mengungkapkan dampak psikologis yang dapat ditimbulkan oleh wabah pada manusia, di masyarakat dapat memicu gejala kejiwaan tanpa penyakit mental, memperburuk kondisi orang-orang dengan penyakit mental yang sudah ada sebelumnya dan dapat memicu gangguan mental. ${ }^{2}$ Kecemasan terjadi ketika di atas tingkat normal, melemahkan sistem kekebalan tubuh dan akibatnya risiko infeksi virus meningkat. ${ }^{35}$

Responden pada penelitian ini sebagian besar (64\%) yaitu paramedis yang terdiri dari Perawat, Bidan, Sarjana Kesehatan Masyarakat dan $16 \%$ masyarakat umum, dimana penelitian sebelumnya bahwa para profesional kesehatan memiliki kesadaran yang lebih baik, sikap positif terhadap pandemi dan mereka mengalami tingkat kecemasan yang rendah. Setelah epidemi H1N1, terlihat bahwa proporsi yang signifikan dari masyarakat umum tidak menyadari keseriusan dan langkah-langkah pencegahan epidemi. ${ }^{17}$

Rasa cemas yang muncul akibat pandemi Covid-19 dapat disebabkan oleh adanya stigma yang ada di masyarakat. Covid-19 ini menimbulkan dampak psikologis dan sosial dengan adanya stigma di masyarakat sama halnya dengan penyakit kusta. Rasa cemas akibat stigma kusta membuat mereka pasien belum siap menerima penyakit sehingga bisa menyebabkan gangguan psikologis. Masalah psikologis dapat mempengaruhi keadaan intelektual, emosional, spiritual penderita penyakit kronik. $^{36}$ 


\section{Kesimpulan}

Ada hubungan antara kondisi ekonomi, stigma, tingkat religiusitas dengan upaya preventif Covid-19, sedangkan tidak ada hubungan antara kecemasan dengan upaya preventif Covid-19. Hasil analisis multivariate variable yang paling dominan berpengaruh terhadap upaya preventif Covid-19 adalah kondisi ekonomi dengan Odds Ratio (OR) 5,7, artinya individu yang kondisi ekonominya kurang baik mempunyai resiko sebesar 6 kali untuk melakukan upaya preventif yang rendah dibandingkan dengan individu yang kondisi ekonominya baik.Nilai koefisien regresi diperoleh sebesar 0,63 artinya seseorang yang memiliki kondisi ekonominya baik memiliki probabilitas untuk melakukan upaya preventif yang tinggi sebesar $63 \%$.

\section{Daftar Pustaka}

1. Tsamakis K, Rizos E, Manolis A, et al. [Comment] COVID-19 pandemic and its impact on mental health of healthcare professionals. Exp Ther Med. Published online 2020:3451-3453. doi:10.3892/etm.2020.8646

2. Ho CSH, Chee CYI, Psychiatry M, Ho RCM. Mental Health Strategies to Combat the Psychological Impact of COVID-19 Beyond Paranoia and Panic. Published online 2020:1-6.

3. ASEAN Policy Brief. Economic Impact of Covid-19 Outbreak on ASEAN. Assoc Southeast Asian Nations. 2020;(April):1-17.

4. Irfan M, Naeem F. Coping with COVID19: Urgent need for building resilience through Cognitive Coping With COVID-19: Urgent Need For Building Resilience Through Cognitive Behavior Therapy. 2020;(May):10-13. doi:10.35845/kmuj.2020.20194

5. Mahmud A, Islam MR. Social Stigma as a Barrier to Covid-19 Responses to
Community Well-Being in Bangladesh. Int J Community Well-Being. Published online 2020. doi:10.1007/s42413-02000071-w

6. Nursalam N, Sukartini T, Priyantini D, Mafula D, Efendi F. Risk factors for psychological impact and social stigma among people facing COVID 19: A systematic review. Syst Rev Pharm. 2020;11(6):1022-1028. doi:10.31838/srp.2020.6.146

7. Xiang M-Q, Tan X-M, Sun J, et al. Relationship of Physical Activity With Anxiety and Depression Symptoms in Chinese College Students During the COVID-19 Outbreak. Front Psychol. 2020;11(November):1-7. doi:10.3389/fpsyg.2020.582436

8. Shiina A, Niitsu T, Kobori O, et al. Relationship between perception and anxiety about COVID-19 infection and risk behaviors for spreading infection: A national survey in Japan. Brain, Behav Immun - Heal. 2020;6(May):100101. doi:10.1016/j.bbih.2020.100101

9. Torales J, O'Higgins M, CastaldelliMaia JM, Ventriglio A. The outbreak of COVID-19 coronavirus and its impact on global mental health. Int $J$ Soc Psychiatry. 2020;66(4):317-320. doi:10.1177/0020764020915212

10. Tull MT, Edmonds KA, Scamaldo KM, Richmond JR, Rose JP, Gratz KL. Psychological Outcomes Associated with Stay-at-Home Orders and the Perceived Impact of COVID-19 on Daily Life. Psychiatry Res. 2020;289(April):113098. doi:10.1016/j.psychres.2020.113098

11. Thomas J, Barbato M. Positive religious coping and mental health among christians and muslims in response to the covid-19 pandemic. Religions. 2020;11(10):1-13. doi:10.3390/rel11100498

12. Septadina IS, Sutysna H. Holy Qur'an Recitation To Overcome Anxiety. Int J Islam Med. 2020;1(1):31-36. 
doi:10.37275/ijim.v1i1.4

13. Kranz D, Niepel C, Botes E, Greiff S. Religiosity Predicts Unreasonable Coping With COVID-19. Psycholog Relig Spiritual. 2020;2(999). doi:10.1037/rel0000395

14. Indri Seta Septadina. HEALTHY LIVING PATTERNS TO PREVENT COVID-19. In: Conferences of Medical Sciences Dies Natalis Faculty of Medicine Universitas Sriwijaya. Vol 2. Faculty of Medicine, Universitas Sriwijaya; 2020:107-112. doi:10.32539/dies.v2i1.47

15. Fitriani A. Annisa Fitriani, Peran Religiusitas Dalam...... 2016;(1).

16. Yahya IS, Abidin Z. Hubungan Antara Religiusitas Dengan Intensi Prososial Pada Siswa-Siswi Madrasah Aliyah Muhammadiyah Kudus. Empati. 2019;7(4):339-344.

17. Roy D, Tripathy S, Kumar S, Sharma N, Kumar S, Kaushal V. Study of knowledge, attitude, anxiety \& perceived mental healthcare need in Indian population during COVID-19 pandemic. Asian $J$ Psychiatr. 2020;51(April):102083. doi:10.1016/j.ajp.2020.102083

18. Pak A, Adegboye OA, Adekunle AI, Rahman KM, McBryde ES, Eisen DP. Economic Consequences of the COVID19 Outbreak: the Need for Epidemic Preparedness. Front Public Heal. 2020;8(May):1-4.

doi:10.3389/fpubh.2020.00241

19. Ristyo S, Imam A, Pepin N. Hubungan Tingkat Sosial Ekonomi dengan Angka Kejadian TB Paru BTA Positif di Wilayah Kerja Puskesmas Peterongan Jombang. Progr Keperawatan STIKES Pemkab Jombang. 2012;2012:31-38.

20. Suhrcke M, Stuckler D, Suk JE, et al. The impact of economic crises on communicable disease transmission and control: A systematic review of the evidence. PLoS One. 2011;6(6). doi:10.1371/journal.pone.0020724
21. Rajkumar RP. The relationship between measures of religiosity and the prevalence and outcome of COVID-19: a population-level pilot study. :1-9.

22. Herawati C, Abdurakhman RN, Rundamintasih N. Peran Dukungan Keluarga, Petugas Kesehatan dan Perceived Stigma dalam Meningkatkan Kepatuhan Minum Obat pada Penderita Tuberculosis Paru. J Kesehat Masy Indones. 2020;15(1):19. doi:10.26714/jkmi.15.1.2020.19-23

23. Abdelhafiz AS, Alorabi M. Social Stigma: The Hidden Threat of COVID19. Front Public Heal. 2020;8(August):2-5. doi:10.3389/fpubh.2020.00429

24. Putri MA, Utomo B. Psycoeducative Family Therapy Mempengaruhi Pengetahuan, Dukungan Keluarga Dan Stigma Kusta. J Ners. 2016;11(Rafferty):88-98.

25. Dwinantoaji H, Dw S. Human security, social stigma, and global health: the COVID-19 pandemic in Indonesia. 2020;52(3):72-79.

26. Ramaci T, Barattucci M, Ledda C, Rapisarda V. Social Stigma during COVID-19 and its Impact on HCWs Outcomes Social Stigma during COVID-19 and its Impact on HCWs Outcomes. 2020;(May). doi:10.3390/su12093834

27. Cucu Herawati et all. Effect Of Psychoeducation-Modification On The Improvement Of Spiritual Respone, Perception Stigma, Anxiety Level and Cortisol Levels Among Lepers. Indian J Public Heal Res Dev. 2019;11.

28. Syahrir A, Rahem A, Prayoga A. Religiusitas Mahasiswa Farmasi UIN Malang Selama Pandemi Covid-19. Published online 2020:25-34.

29. Bintari N, Dantes P, Sulastri M. Korelasi Konsep Diri Dan Sikap Religiusitas Terhadap Kecenderungan Perilaku Menyimpang Dikalangan Siswa Pada Kelas Xi Sma Negeri 4 Singaraja Tahun 
Ajaran 2013/2014. J Jur Bimbing dan Konseling Undiksha. 2013;2(1).

30. Jaenudin U, Tahrir T. Studi Religiusitas, Budaya Sunda, dan Perilaku Moral pada Masyarakat Kabupaten Bandung. J Psikol Islam dan Budaya. 2019;2(1):1-8. doi:10.15575/jpib.v2i1.3445

31. L. Sheng, M. Christopher AM. Religion, senescence and mental health: the end of life is not the end of hope. Physiol Behav. 2016;176(1):100-106. doi:10.1016/j.gde.2016.03.011

32. Steglitz J, Ng R, Mosha JS, Kershaw T. Divinity and distress: The impact of religion and spirituality on the mental health of HIV-positive adults in Tanzania. AIDS Behav. 2012;16(8):2392-2398. doi:10.1007/s 10461-012-0261-7

33. Kholik K, Suarti NKA, Garnika E, Hidayatullah MT. The Relationship of Student's Knowledge Level with Anxiety and Precautions the Spread Covid19 in West Nusa Tenggara. $J$ Kesehat Lingkung. 2020;12(1si):45. doi:10.20473/jkl.v12i1si.2020.45-50

34. Blbas HTA, Aziz KF, Nejad SH, Barzinjy AA. Phenomenon of depression and anxiety related to precautions for prevention among population during the outbreak of COVID-19 in Kurdistan Region of Iraq: based on questionnaire survey. J Public Heal. Published online 2020. doi:10.1007/s10389-020-01325-9

35. IFRC, Unicef W. Social Stigma associated with COVID-19 A guide to preventing and addressing. 2020;(February):1-5.

36. Herawati C, Herlinawati, Kristanti I. Improvement of Intellectual, Emotional, Spiritual, and Adversity Intelligence After Psychoeducation Modification Among Lepers. Published online 2020. doi:10.2991/ahsr.k.200723.087

1. Tsamakis K, Rizos E, Manolis A, et al. [Comment] COVID-19 pandemic and its impact on mental health of healthcare professionals. Exp Ther Med. Published online 2020:3451-3453. doi:10.3892/etm.2020.8646

2. Ho CSH, Chee CYI, Psychiatry M, Ho RCM. Mental Health Strategies to Combat the Psychological Impact of COVID-19 Beyond Paranoia and Panic. Published online 2020:1-6.

3. ASEAN Policy Brief. Economic Impact of Covid-19 Outbreak on ASEAN. Assoc Southeast Asian Nations. 2020;(April):1-17.

4. Irfan M, Naeem F. Coping with COVID19: Urgent need for building resilience through Cognitive Coping With COVID-19: Urgent Need For Building Resilience Through Cognitive Behavior Therapy. 2020;(May):10-13. doi:10.35845/kmuj.2020.20194

5. Mahmud A, Islam MR. Social Stigma as a Barrier to Covid-19 Responses to Community Well-Being in Bangladesh. Int J Community Well-Being. Published online 2020. doi:10.1007/s42413-02000071-w

6. Nursalam N, Sukartini T, Priyantini D, Mafula D, Efendi F. Risk factors for psychological impact and social stigma among people facing COVID 19: A systematic review. Syst Rev Pharm. 2020;11(6):1022-1028. doi:10.31838/srp.2020.6.146

7. Xiang M-Q, Tan X-M, Sun J, et al. Relationship of Physical Activity With Anxiety and Depression Symptoms in Chinese College Students During the COVID-19 Outbreak. Front Psychol. 2020;11(November):1-7. doi:10.3389/fpsyg.2020.582436

8. Shiina A, Niitsu T, Kobori $\mathrm{O}$, et al. Relationship between perception and anxiety about COVID-19 infection and risk behaviors for spreading infection: A national survey in Japan. Brain, Behav Immun - Heal. 2020;6(May):100101. doi:10.1016/j.bbih.2020.100101

9. Torales J, O'Higgins M, Castaldelli- 
Maia JM, Ventriglio A. The outbreak of COVID-19 coronavirus and its impact on global mental health. Int $J$ Soc Psychiatry. 2020;66(4):317-320. doi:10.1177/0020764020915212

10. Tull MT, Edmonds KA, Scamaldo KM, Richmond JR, Rose JP, Gratz KL. Psychological Outcomes Associated with Stay-at-Home Orders and the Perceived Impact of COVID-19 on Daily Life. Psychiatry Res. 2020;289(April):113098.

doi:10.1016/j.psychres.2020.113098

11. Thomas J, Barbato M. Positive religious coping and mental health among christians and muslims in response to the covid-19 pandemic. Religions. 2020;11(10):1-13. doi:10.3390/rel11100498

12. Septadina IS, Sutysna H. Holy Qur'an Recitation To Overcome Anxiety. Int J Islam Med. 2020;1(1):31-36. doi:10.37275/ijim.v1i1.4

13. Kranz D, Niepel C, Botes E, Greiff S. Religiosity Predicts Unreasonable Coping With COVID-19. Psycholog Relig Spiritual. 2020;2(999). doi:10.1037/re10000395

14. Indri Seta Septadina. HEALTHY LIVING PATTERNS TO PREVENT COVID-19. In: Conferences of Medical Sciences Dies Natalis Faculty of Medicine Universitas Sriwijaya. Vol 2. Faculty of Medicine, Universitas Sriwijaya; 2020:107-112. doi:10.32539/dies.v2i1.47

15. Fitriani A. Annisa Fitriani, Peran Religiusitas Dalam...... 2016;(1).

16. Yahya IS, Abidin Z. Hubungan Antara Religiusitas Dengan Intensi Prososial Pada Siswa-Siswi Madrasah Aliyah Muhammadiyah Kudus. Empati. 2019;7(4):339-344.

17. Roy D, Tripathy S, Kumar S, Sharma N, Kumar S, Kaushal V. Study of knowledge, attitude, anxiety \& perceived mental healthcare need in Indian population during COVID-19 pandemic. Asian $J$ Psychiatr. 2020;51(April):102083. doi:10.1016/j.ajp.2020.102083

18. Pak A, Adegboye OA, Adekunle AI, Rahman KM, McBryde ES, Eisen DP. Economic Consequences of the COVID19 Outbreak: the Need for Epidemic Preparedness. Front Public Heal. 2020;8(May):1-4.

doi:10.3389/fpubh.2020.00241

19. Ristyo S, Imam A, Pepin N. Hubungan Tingkat Sosial Ekonomi dengan Angka Kejadian TB Paru BTA Positif di Wilayah Kerja Puskesmas Peterongan Jombang. Progr Keperawatan STIKES Pemkab Jombang. 2012;2012:31-38.

20. Suhrcke M, Stuckler D, Suk JE, et al. The impact of economic crises on communicable disease transmission and control: A systematic review of the evidence. PLoS One. 2011;6(6). doi:10.1371/journal.pone.0020724

21. Rajkumar RP. The relationship between measures of religiosity and the prevalence and outcome of COVID-19: a population-level pilot study. :1-9.

22. Herawati C, Abdurakhman RN, Rundamintasih N. Peran Dukungan Keluarga, Petugas Kesehatan dan Perceived Stigma dalam Meningkatkan Kepatuhan Minum Obat pada Penderita Tuberculosis Paru. J Kesehat Masy Indones. 2020;15(1):19. doi:10.26714/jkmi.15.1.2020.19-23

23. Abdelhafiz AS, Alorabi M. Social Stigma: The Hidden Threat of COVID19. Front Public Heal. 2020;8(August):2-5. doi:10.3389/fpubh.2020.00429

24. Putri MA, Utomo B. Psycoeducative Family Therapy Mempengaruhi Pengetahuan, Dukungan Keluarga Dan Stigma Kusta. J Ners. 2016;11(Rafferty):88-98.

25. Dwinantoaji H, Dw S. Human security, social stigma, and global health: the COVID-19 pandemic in Indonesia. 2020;52(3):72-79. 
26. Ramaci T, Barattucci M, Ledda C, Rapisarda V. Social Stigma during COVID-19 and its Impact on HCWs Outcomes Social Stigma during COVID-19 and its Impact on HCWs Outcomes. 2020;(May). doi:10.3390/su12093834

27. Cucu Herawati et all. Effect Of Psychoeducation-Modification On The Improvement Of Spiritual Respone, Perception Stigma, Anxiety Level and Cortisol Levels Among Lepers. Indian J Public Heal Res Dev. 2019;11.

28. Syahrir A, Rahem A, Prayoga A. Religiusitas Mahasiswa Farmasi UIN Malang Selama Pandemi Covid-19. Published online 2020:25-34.

29. Bintari N, Dantes P, Sulastri M. Korelasi Konsep Diri Dan Sikap Religiusitas Terhadap Kecenderungan Perilaku Menyimpang Dikalangan Siswa Pada Kelas Xi Sma Negeri 4 Singaraja Tahun Ajaran 2013/2014. J Jur Bimbing dan Konseling Undiksha. 2013;2(1).

30. Jaenudin U, Tahrir T. Studi Religiusitas, Budaya Sunda, dan Perilaku Moral pada Masyarakat Kabupaten Bandung. J Psikol Islam dan Budaya. 2019;2(1):1-8. doi:10.15575/jpib.v2i1.3445

31. L. Sheng, M. Christopher AM. Religion, senescence and mental health: the end of life is not the end of hope. Physiol Behav. 2016;176(1):100-106. doi:10.1016/j.gde.2016.03.011

32. Steglitz J, Ng R, Mosha JS, Kershaw T. Divinity and distress: The impact of religion and spirituality on the mental health of HIV-positive adults in Tanzania. AIDS Behav. 2012;16(8):2392-2398. doi:10.1007/s 10461-012-0261-7

33. Kholik K, Suarti NKA, Garnika E, Hidayatullah MT. The Relationship of Student's Knowledge Level with Anxiety and Precautions the Spread Covid19 in West Nusa Tenggara. $J$ Kesehat Lingkung. 2020;12(1si):45. doi:10.20473/jkl.v12i1si.2020.45-50
34. Blbas HTA, Aziz KF, Nejad SH, Barzinjy AA. Phenomenon of depression and anxiety related to precautions for prevention among population during the outbreak of COVID-19 in Kurdistan Region of Iraq: based on questionnaire survey. J Public Heal. Published online 2020. doi:10.1007/s10389-020-01325-9

35. IFRC, Unicef W. Social Stigma associated with COVID-19 A guide to preventing and addressing. 2020;(February):1-5.

36. Herawati C, Herlinawati, Kristanti I. Improvement of Intellectual, Emotional, Spiritual, and Adversity Intelligence After Psychoeducation Modification Among Lepers. Published online 2020. doi:10.2991/ahsr.k.200723.087 

